\author{
dr inż. Michał Dominik STASIAK \\ Uniwersytet Ekonomiczny w Poznaniu \\ e-mail: michal.stasiak@ue.poznan.pl
}

DOI: $10.15290 /$ ose.2017.03.87.12

\title{
ANALIZA FALOWA KURSU USD/PLN W REPREZENTACJI BINARNEJ
}

\begin{abstract}
Streszczenie
Kurs pary walutowej można zobrazować w postaci reprezentacji binarnej. Algorytm binaryzacji zamienia kurs reprezentowany przez dane tikowe na odpowiedni ciag binarny. Podstawą algorytmu jest dyskretyzacja kursu, w której każdej zmianie wartości, równej zadanej jednostce dyskretyzacji, jest przypisywana wartość binarna zgodna $z$ kierunkiem zmiany kursu. Badania statystyczne przeprowadzone przez autora potwierdzily istnienie zależności w binarnej reprezentacji kursu między historycznymi zmianami a dalszym kierunkiem zmian. Reprezentowany binarnie kurs może być zatem wykorzystany do wyznaczania kierunku i zakresu przyszłych zmian, a w konsekwencji budowy systemów HFT charakteryzujących się dodatnią stopą zwrotu. Jedną z podstawowych metod analizy technicznej jest analiza falowa. W artykule przedstawiono zastosowanie analizy falowej dla reprezentacji binarnej. W tym celu zaproponowano algorytmy pozwalające na detekcje fal, następnie dokonano analizy odpowiednich parametrów fal oraz ich wpływu na kierunek przyszłych zmian kursu walutowego USD/PLN. Proces binaryzacji kursu i algorytm wyznaczania fal został przeprowadzony na podstawie oprogramowania napisanego przez autora w jezzyku MQL4 i C++.
\end{abstract}

Słowa kluczowe: rynek walutowy, FOREX, analiza techniczna, analiza falowa

\section{BINARY REPRESENTATION OF USD/PLN EXCHANGE RATE: A WAVE ANALYSIS}

\section{Summary}

The exchange rate of a currency pair can be represented in a binary form. The binarization algorithm converts rates presented in tick data into an appropriate binary string. The basis for this algorithm is provided by an exchange rate discretization, in which each change in value equal to a given discretization unit is assigned a binary value, which corresponds to the direction of change. Statistical research performed by the author confirms dependencies of previous changes and future change of direction in binary representation of exchange rates. Thus, the binary representation can be applied in appointing the direction and scope of future changes, and consequently in the construction of HFT systems with positive rates of return. Wave analysis is one of the basic methods of technical analysis. The paper presents the application of wave analysis for binary representation. For this purpose, algorithms for wave detection are proposed, followed by the analysis of relevant wave parameters and their impact on the direction of future changes in the USD / PLN exchange rate. The binarization process and algorithm for appointing pairs is performed based on the author's proprietary software written in the MQL4 and C++ language.

Key words: currency market, FOREX, technical analysis, wave analysis

JEL: F31, G11, G14, C49 


\section{Wstęp}

Kursy par walutowych zwyczajowo są prezentowane w formie wykresu świecowego. Każdej zmianie kursu w określonym okresie są przypisywane cztery wartości, takie jak: wartość max, min, otwarcia i zamknięcia. Taka reprezentacja jest wykorzystywana w metodach wizualnych analizy technicznej. Wskaźniki analizy technicznej również są wyznaczone na podstawie parametrów lub wybranego parametru świecy [Murphy, 1999; Schlossberg, 2006; Yazdi, Lashkari, 2013; Valcu, 2004; Neely, Weller, 2011]. Stosowanie reprezentacji świecowej prowadzi do utraty wartości informacyjnej dotyczącej zmienności kursu wewnątrz świecy. Zastosowanie reprezentacji binarnej kursu walutowego umożliwia bardziej precyzyjną i skuteczniejszą analizę kursu walutowego. Takie podejście eliminuje w analizie technicznej okresy braku zmienności, np. noce, a jednocześnie zachowuje informację o kierunku i poziomie zmian, która dla potencjalnego inwestora jest najbardziej istotna.

Kurs USD/PLN w reprezentacji binarnej został poddany analizie statystycznej w celu zbadania istnienia możliwych zależności pomiędzy danymi historycznymi a aktualnymi zmianami ceny. W analizie statystycznej posłużono się zestawem testów z pakietu SP800-22 [Rukhin i in. 2010], wykorzystywanych m.in. przez National Institute of Standards and Technology (NIST) do badania generatorów liczb pseudolosowych oraz certyfikacji modułów kryptograficznych.

Możliwość zastosowania reprezentacji binarnej kursu walutowego do budowy modeli predykcyjnych była rozważana w pracy Stasiaka [2016], w której zaproponowano stanowy model reprezentacji binarnej SMBR (ang. State Model of Binary Representatin). Model pozwala na określenie prawdopodobieństw przyszłych zmian kursu.

Większość metod analizy technicznej wykorzystuje zależności falowe, np.: analizę formacji, analizę trendu itd. lub popularną wśród analityków teorię fal Elliotta [Bickford, 2007; Murphy, 1999; Schlossberg, 2006; Frost, Prechter, 1995]. W metodach tych brakuje sprecyzowanych warunków detekcji początku i końca poszczególnych fal. Detekcji fali dokonuje analityk lub inwestor w sposób indywidualny. W konsekwencji uniemożliwia to jednoznaczną weryfikację istnienia zależności falowych na rynku walutowym.

Celem artykułu jest propozycja algorytmów detekcji fal pozwalających na jednoznaczną analizę charakteru występujących fal oraz wykazanie na przykładzie badanej pary walutowej istnienia zależności między parametrami fali a prawdopodobieństwem kierunku przyszłej zmiany kursu walutowego.

W artykule poddano analizie dwa algorytmy, które służą precyzyjnemu wyznaczaniu fal w reprezentacji binarnej. Przedstawiono także przykład analizy parametrów fal występujących w pięcioletnich notowaniach kursu USD/PLN z okresu 01.01.201001.01.2015. W analizie posłużono się tikowymi danymi pochodzącymi od brokera Dukascopy.

Artykuł składa się z trzech rozdziałów. W rozdziale drugim ukazano reprezentację binarna. W rozdziale trzecim opisano dwa algorytmy detekcji fal oraz na ich podstawie analizę badanej pary walutowej. Artykuł kończy podsumowanie zawierające wnioski z tych badań. 


\section{Reprezentacja binarna kursu walutowego}

Na rynku walutowym kursy zmieniają się średnio co sekundę. Tak wysoka częstotliwość zmian w rzeczywistości uniemożliwia prezentację danych tikowych. W celu analizy kursu w dłuższych przedziałach czasowych, kurs walutowy praktycznie przedstawiaja wszystkie platformy brokerskie (np.: MetaTrader, JForex itd.) w formie wykresu świecowego dla danego interwału czasowego. W reprezentacji świecowej kurs opisuje się dzięki czterem parametrom tworzącym świecę (cena otwarcia, cena zamknięcia, cena maksymalna oraz cena minimalna) dla danego okresu. Kurs w reprezentacji świecowej jest wykorzystywany przez techniki wizualnej analizy technicznej. Kurs w takiej reprezentacji (lub jeden z parametrów świecy, np. kurs zamknięcia) jest również wykorzystywany jako dana wejściowa przez wskaźniki analizy technicznej (np.: MACD, RSI) [Murphy, 1999; Schlossberg, 2006; Yazdi, Lashkari, 2013; Valcu, 2004; Neely, Weller, 2011]. Reprezentacja świecowa - będąca przekształceniem danych tickowych ${ }^{1}$ na dziedzinę czasu - prowadzi do utraty części informacji dotyczących zmienności kursu i trudności interpretacyjnych. Jednocześnie mogą występować zmiany o dużej amplitudzie trwające kilka minut (np. podczas prezentacji danych makroekonomicznych), a także wielogodzinne - wielokrotnie mniejsze - wahania podczas nocy [Murphy, 1999; Schlossberg, 2006]. Taki charakter analizowanych danych przyczynia się do dużej złożoności modeli określonych w dziedzinie czasu.

Analizowanie danych tickowych jest skomplikowane ze względu na wielkość danych oraz fakt rejestracji parametrów, które nie maja wartości informacyjnej, takich jak losowe fluktuacje kursu. Stosując reprezentację binarną, przedstawiono kurs w zależności od wielkości zmian, a nie czasu, jak w przypadku reprezentacji świecowej [Stasiak, 2015]. W reprezentacji binarnej kluczowa jest zmiana kursu, natomiast czas jej trwania całkowicie pomija się. Każdej zmianie kursu o przyjęta jednostkę dyskretyzacji przypisano wartości binarną 0 lub 1. Algorytm dyskretyzacji dla początkowej wartości kursu określa górną i dolna granicę zmiany. Jest ona równa dodatniemu i ujemnemu przyrostowi kursu o zadana jednostkę dyskretyzacji. Jeśli kurs spadnie poniżej dolnej granicy, algorytm przypisuje wartość binarną równą zeru (0), zaś w przypadku wzrostu ceny powyżej górnej granicy, algorytm przypisuje wartość binarną równa jeden (1). W następnych krokach algorytm wyznacza kolejne wartości graniczne w stosunku do aktualnego kursu. W efekcie działania algorytmu kurs pary walutowej ukazuje się w postaci ciagu binarnego (np. 01011101) [Stasiak, 2015]. Na rysunku 1. zobrazowano przykładową zamianę kursu na ciag binarny. Jeśli wystąpią luki cenowe, np. po weekendach, algorytm sprawdza, która wartość zostałaby osiagnięta i zwraca odpowiedni rezultat. Następnie kolejne wartości graniczne są określane w odniesieniu do pierwszej ceny po luce cenowej.

\footnotetext{
${ }^{1}$ Dane tickowe (ang. tick data) to najbardziej precyzyjne dane, w których są zarejestrowane wszystkie zmiany (nawet o najmniejszą możliwą wartość) kursu walutowego.
} 
RYSUNEK 1.

Przykład reprezentacji binarnej kursu walutowego

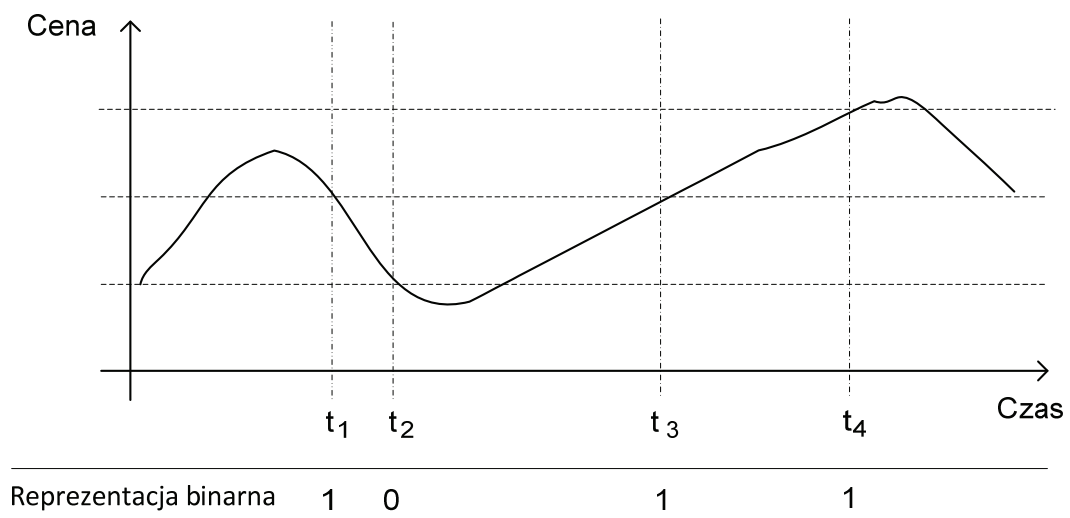

Źródło: [Stasiak, 2016].

\subsection{Zalety stosowania reprezentacji binarnej}

W analizie świecowej, np. o interwale godzinnym, szereg zmian o zasięgu kilkudziesięciu pipsów ${ }^{2}$ może być reprezentowanych przez jedną świecę. W konsekwencji powoduje to utratę wielu informacji dotyczących częstotliwości i kierunku pojedynczych ruchów ceny. Na podstawie kursu przedstawionego w reprezentacji świecowej, w wielu przypadkach trudno jest zweryfikować, czy dana transakcja zakończyłaby się zyskiem, czy stratą inwestora. Sytuacja taka została przedstawiona na rysunku 2. W pierwszym przypadku (rysunek 2a) inwestor osiagnąłby zysk, natomiast w drugim (rysunek $2 \mathrm{~b}$ ) poniósłby stratę, choć oba notowania obrazuje taka sama świeca. W sytuacji zastosowania reprezentacji binarnej, najważniejsze dla analizy technicznej informacje - kierunek oraz zasięg zmian - są rejestrowane. Czas trwania zmiany w reprezentacji binarnej jest pomijany, ponieważ ten parametr dla inwestora ma znaczenie drugorzędne (w przypadku zastosowania kilkudziesięciu pipsowych jednostek dyskretyzacji czas zmiany jest liczony w minutach lub godzinach). Reprezentacja binarna posiada zatem większą wartość informacyjną dla inwestora i w następstwie umożliwia precyzyjną analizę kursu walutowego.

${ }^{2}$ Pips to podstawowa jednostka zmiany kwotowań kursu walutowego. W przypadku kursu walutowego USD/PLN wynosi 0,0001. 
RYSUNEK 2.

Przykład dwóch różnych zmian kursu generujących stratę (a) lub zysk (b) $z$ transakcji, reprezentowanych przez tę samą świecę
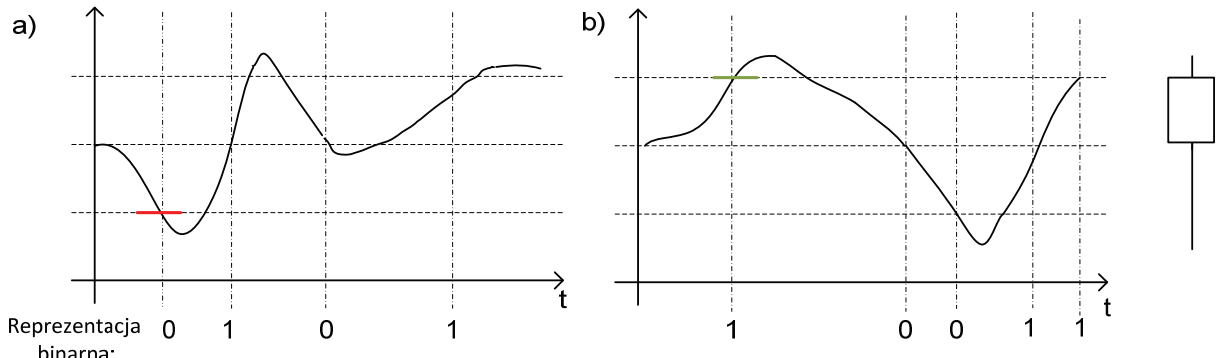

Źródło: opracowanie własne.

\subsection{Uzasadnienie możliwości zastosowania reprezentacji binarnej}

Najważniejszym parametrem reprezentacji binarnej jest właściwy dobór jednostki dyskretyzacji. W zależności od przyjętej wartości otrzymany przebieg zmian kursu może mieć różny charakter. Wybór zbyt małej jednostki dyskretyzacji powoduje rejestrację losowych fluktuacji, tzw. szumu. Rejestracja losowych fluktuacji może prowadzić do trudności w analizie przedstawionego kursu (problem istnienia i filtracji szumu był wielokrotnie poruszany w kontekście analizy technicznej [Lo, Mamaysky, Wang, 2000; Logue, Sweeney, 1977; Neely, Weller, 2011]. Jednocześnie wybór zbyt dużej jednostki dyskretyzacji spowoduje rejestracje tylko dużych, bardzo rzadkich zmian, co w konsekwencji przyczyni się do utraty wielu cennych informacji dotyczących zmienności kursu. Optymalna wielkość jednostki dyskretyzacji powinna uwzględniać kwestie praktyczne, np.: wielkość spreadu, możliwość zawieranie transakcji (w których TP i SL są oddalone od ceny o jednostkę dyskretyzacji). Biorąc pod uwage powyższe rozważania, w artykule przyjęto jednostkę dyskretyzacji na poziomie 40 pipsów dla badanej pary walutowej.

W celu dalszej analizy kursu, w reprezentacji binarnej z przyjętą jednostką dyskretyzacji należy określić charakter otrzymanego ciagu binarnego. W związku z tym zweryfikowano, czy ciag binarny ma charakter losowy, tzn. czy występowanie kolejnych zmian jest niezależne od historii przebiegu. W przypadku potwierdzenia hipotezy losowości dalsza analiza kursu w reprezentacji binarnej dla zadanej jednostki dyskretyzacji byłaby bezcelowa. Weryfikacji hipotezy losowości posłużył zestaw czterech testów statystycznych pakietu SP800-22 [Rukhin i in. 2010], zalecanych przez NIST. Wybrano następujące testy: pojedynczych bitów, pokerowy, serii, długich serii w bloku. Jednoczesny wynik pozytywny pozwala na zakwalifikowanie danych jako losowe. W badaniach przyjęto poziom istotności równy 0.05 . 
Badaniu poddano dane historyczne kursu USD/PLN w reprezentacji binarnej otrzymane dla przyjętej 40-pipsowej jednostki dyskretyzacji z okresu 5 lat (01.01.201101.01.2016). Hipoteza losowości została potwierdzona jedynie przez test pojedynczych bitów, co oznacza porównywalną liczbę zer i jedynek w badanym okresie [Rukhin i in. 2010; Chung, 2012]. Trzy pozostałe testy odrzuciły hipotezę losowości. Rezultat ten można interpretować jako możliwość istnienia pewnych prawidłowości dotyczących różnych częstotliwości występowania określonych wzorców sekwencji zerojedynkowych [Godbole, Papastavridis, 1994; Menezes, Oorschot, Vanstone, 1996]. Podobne rezultaty otrzymano dla innych wartości jednostek dyskretyzacji [Stasiak, 2015]. Podsumowując, wyniki testów statystycznych wskazują na możliwość istnienia zależności między historycznymi przebiegami a przyszłym kierunkiem zmian. Taki charakter danych uzasadnia dalsze badania nad analiza zmian kursu przedstawiona w reprezentacji binarnej.

\section{Fale $w$ reprezentacji binarnej}

Pojęcie fali występuje w większości technik analizy kursów [Bickford, 2007; Murphy, 1999; Schlossberg, 2006]. Na przykład w wizualnej analizie wykresu kolejne fale o danych parametrach tworzą formację itd. W teorii Elliotta (powszechnie stosowanej przez analityków rynku walutowego w analizie technicznej) sformułowano szereg zależności pomiędzy parametrami kolejnych fal [Frost, Prechter, 1995]. Obecność fal na rynku walutowym można również uzasadnić analizą zachowania inwestorów [Oberlechner, 2005]. Większe ruchy na rynku są rezultatem publikacji ważnych danych makroekonomicznych, np. stóp procentowych lub nagłych zmian politycznych, np. dymisji w rządzie. W takich przypadkach inwestorzy zawierający transakcję kierują się otrzymanymi informacjami jeszcze przez określony czas, tworząc fale o określonym zasięgu i czasie trwania.

\subsection{Definicje i rodzaje fal}

Podstawa dotychczasowych metod analizy technicznej, opartych na badaniu fal i ich parametrów, jest wizualna analiza wykresu świecowego [Frost, Prechter 1995; Murphy, 1999]. Pomijając fakt utraty wartości informacyjnej wykresu świecowego, efektywność danej techniki zależy od indywidualnej oceny analityka. Bez określonych, precyzyjnych zasad detekcji fal, weryfikacja istnienia potencjalnych zależności falowych na rynku walutowym oraz analiza parametrów fal z wykorzystaniem danych historycznych jest niemożliwa. $\mathrm{Na}$ rysunku 3. zobrazowano dwie (z wielu różnych) możliwości wyznaczenia fal przez analityka bądź inwestora dla danego wykresu kursu.

Chcąc zweryfikować obecne teorie i metody analizy technicznej, bazujące na analizie fal, albo zaproponować nowe metody modelowania rynku z wykorzystaniem zależności falowych, konieczne jest precyzyjne zdefiniowanie algorytmu detekcji początku i końca danej fali, którego działanie będzie uniezależnione od wiedzy i indywidualnych preferencji inwestora. 
RYSUNEK 3.

\section{Różne możliwości wizualnej detekcji fal: a) jedna fala, b) pięć fal}

a)

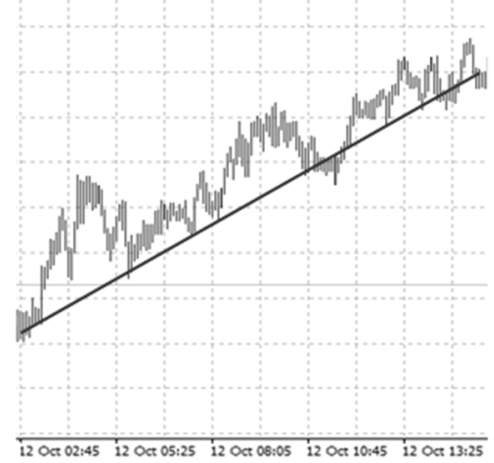

b)

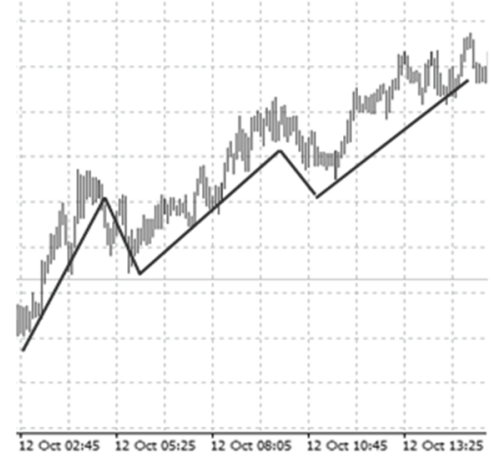

Źródło: opracowanie własne.

\subsection{Algorytm detekcji fal w reprezentacji binarnej (ADFRB)}

W większości teorii (np. w teorii Elliotta) i metod analizy technicznej kurs może znajdować się aktualnie w fali wzrostowej lub spadkowej [Frost, Prechter, 1995; Murphy, 1999]. Koniec fali spadkowej jest równoznaczny z początkiem fali wzrostowej i na odwrót. Analogiczne podejście zastosowano w przedstawionym algorytmie. Podstawą detekcji fal w reprezentacji binarnej jest przekroczenie określonych progów wartości średnich wzrostów bądź spadków kursu walutowego. W algorytmie detekcji fal w reprezentacji binarnej definiuje się dwa wejściowe parametry, od których zależy dokładność algorytmu. Są to:

- liczba analizowanych zmian historycznych $m$;

- $\quad$ poziom średniej liczby wzrostów/spadków w $m$ poprzedzających zmianach kursu rozpoczynających falę $p$.

Algorytm detekcji fal w reprezentacji binarnej wyznacza średnią wartość spadków oraz wzrostów w $m$ ostatnich zmianach kursu. Jeśli średnia wartość wzrostów przekracza zadany próg $p$, rozpoczyna się fala wzrostowa. Jeśli z kolei wartość spadków przekracza założony próg $p$, rozpoczyna się fala spadkowa. Jeżeli średnia wzrostów i średnia spadków nie przekracza progu $p$, to zakłada się, że trwa kontynuacja bieżącej fali. Algorytm detekcji fali w reprezentacji binarnej przypisuje każdej zmianie rodzaj fali. Algorytm detekcji fal w reprezentacji binarnej można zapisać w poniższy sposób.

1) Wyznaczenie średniej liczby wzrostów $w$ oraz spadków $s$ w $m$ poprzedzających zmianach:

$$
w=\frac{\sum_{i=1}^{m} x_{i}}{m}, \quad s=\frac{\sum_{i=1}^{m}\left|x_{i}-1\right|}{m},
$$

gdzie $x_{i}$ to $i$-ta zmiana w reprezentacji binarnej. 
2) Jeżeli:

$w>p$ to poczatek lub kontynuacja fali wzrostowej,

$s>p$ to początek lub kontynuacja fali spadkowej.

3) Jeżeli:

$w<p$ i $s<p$ to kontynuacja bieżącej fali.

Działanie algorytmu detekcji fal, jego dokładność, częstotliwość rejestrowanych fal itd. zależą od parametrów $m$ i $p$. Od ich wartości również zależy charakter związków pomiędzy parametrami kolejno następujących fal.

\subsection{Algorytm detekcji fal w reprezentacji binarnej z uwzględnieniem okresów konsolidacji (ADFRBK)}

W analizie kursów walutowych, a także innych instrumentów można wyodrębnić okresy charakteryzujące się bardzo małymi wahaniami cen [Murphy, 1999]. Przykładem mogą być godziny nocne na rynku walutowym, np. kurs USD/PLN podczas godzin nocnych w Polsce cechuje się bardzo małymi wahaniami. Założenie, że kurs może znajdować się w fali wzrostowej albo spadkowej powoduje, że okresy konsolidacji są automatycznie klasyfikowane jako kontynuacja danej fali. Takie podejście przyczynia się do pogorszenia jakości modelowania kursu z wykorzystaniem fal. Stąd w artykule zaproponowano algorytm detekcji fal w reprezentacji binarnej z uwzględnieniem okresów konsolidacji. W tym modelu wprowadzono trzeci rodzaj fali - tzw. fali neutralnej - która odpowiada okresowi konsolidacji na rynku. Podobnie jak w przypadku algorytmu ADFRB, w proponowanym algorytmie również wykorzystano poziomy średnich wzrostów i spadków do detekcji danego rodzaju fali. W algorytmie zdefiniowano trzy wejściowe parametry, a mianowicie:

$m$ - liczba analizowanych poprzedzających zmian kursu;

$n$ - poziom średniej liczby wzrostów/spadków w $m$ poprzedzających zmianach kursu, rozpoczynający falę neutralna;

$p$ - poziom średniej liczby wzrostów/spadków w $m$ poprzedzających zmianach kursu rozpoczynających falę,

Algorytm detekcji fal w reprezentacji binarnej można zapisać w poniższy sposób.

1) Wyznaczenie średniej liczby wzrostów $w$ oraz spadków $s \mathrm{w} m$ poprzedzajacych zmianach:

$$
w=\frac{\sum_{i=1}^{m} x_{i}}{m}, \quad s=\frac{\sum_{i=1}^{m}\left|x_{i}-1\right|}{m},
$$

gdzie $x_{i}$ oznacza $i$-tą zmianę w reprezentacji binarnej.

2) Jeżeli:

$w>p$ to poczatek lub kontynuacja fali wzrostowej,

$s>p$ to początek lub kontynuacja fali spadkowej.

3) Jeżeli:

$w<n$ i s $<p$ i trwa fala wzrostowa to początek fali neutralnej, $s<n$ i $w<p$ i trwa fala spadkowa to poczatek fali neutralnej, w pozostałych przypadkach kontynuacja bieżącej fali. 
Algorytm detekcji fal przypisuje każdej zmianie kursu o jednostkę dyskretyzacji odpowiedni rodzaj fali (neutralnej, wzrostowej bądź spadkowej). Podobnie jak w przypadku poprzedniego algorytmu ADFRB, dokładność i częstotliwość rejestrowanych fal zależą od przyjętych parametrów: $m, n$ i $p$. Od ich wartości zależy również charakter związków pomiędzy parametrami kolejno pojawiających się fal.

\subsection{Reprezentacja binarno-falowa}

Po każdej zmianie kursu o przyjęta jednostkę dyskretyzacji można jednoznacznie określić, w jakiej aktualnej fali znajduje się kurs. Można w tym celu wykorzystać jeden $z$ dwóch zaproponowanych w artykule algorytmów. W reprezentacji binarno-falowej każda zmiana kursu o przyjętą jednostkę dyskretyzacji jest reprezentowana przez parę dwóch parametrów. Pierwszy to kierunek zmiany ( 0 dla spadku, 1 dla wzrostu), analogicznie jak w przypadku reprezentacji binarnej. Drugi parametr przedstwia rodzaj aktualnej fali i jest wyznaczony na podstawie odpowiedniego algorytmu detekcji. W przypadku zastosowania pierwszego algorytmu (ADFRB) parametr ten może przyjąć dwie wartości: 1 dla fali wzrostowej, a 0 dla fali spadkowej, natomiast w przypadku zastosowania drugiego proponowanego algorytmu (ADFRBK) parametr może przyjąc trzy wartości: 1 dla fali wzrostowej, 0 dla fali spadkowej i 2 dla fali neutralnej (ukazującej okresy konsolidacji rynku). Reprezentacja binarno-falowa zależy zatem od zastosowanej jednostki dyskretyzacji, przyjętych parametrów i rodzaju algorytmu detekcji fal. Na rysunku 4. zobrazowano przykład reprezentacji binarno-falowej fragmentu kursu, wynikającej z zastosowanego algorytmu detekcji fali.

\section{Reprezentacja binarno-falowa kursu walutowego}

RYSUNEK 4.

\begin{tabular}{|l|l|l|l|l|l|}
\hline 0 & 1 & 1 & 1 & 0 & 1 \\
\hline 0 & 2 & 2 & 1 & 1 & 1 \\
\hline
\end{tabular}

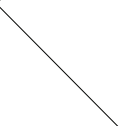

rodzaj aktualnej fali

(0-spadkowa, 1-wzrostowa dla ADFRB)

(0-spadkowa, 1-wzrostowa, 2-neutralna dla ADFRBK)

(0-spadek/1-wzrost)
Źródło: opracowanie własne.

reprezentacja binarna kursu

\subsection{Analiza parametrów fal dla kursu walutowego USD/PLN}

Prawidłowości dotyczące występowania oraz parametry rozkładu długości fal zależą od charakterystyk danej pary walutowej, jak również rodzaju i przyjętych parametrów 
algorytmu detekcji fal. W artykule przedstawiono analizę fal występujących w kursie walutowym USD/PLN. Badaniom poddano notowania historyczne z okresu 5 lat. Przyjęto w nich 40-pipsową jednostkę dyskretyzacji.

Rysunek 5. obrazuje zależność liczby wystapień fal wzrostowych i spadkowych od ich długości, wyrażoną w liczbie zmian kursu o jednostkę dyskretyzacji. W badaniach zastosowano algorytm detekcji fali w reprezentacji binarnej, pozwalający na zarejestrowanie fali wzrostowej i spadkowej (ADFRB) z parametrami $m=8$ i $p=0.7$. Otrzymane rezultaty potwierdziły zbieżny charakter rozkładów długości fal wzrostowych i spadkowych.

RYSUNEK 5.

Zależność liczby wystąpień fal wzrostowych i spadkowych od ich długości w reprezentacji binarno-falowej - ADFRB $(m=8, p=0.7)$

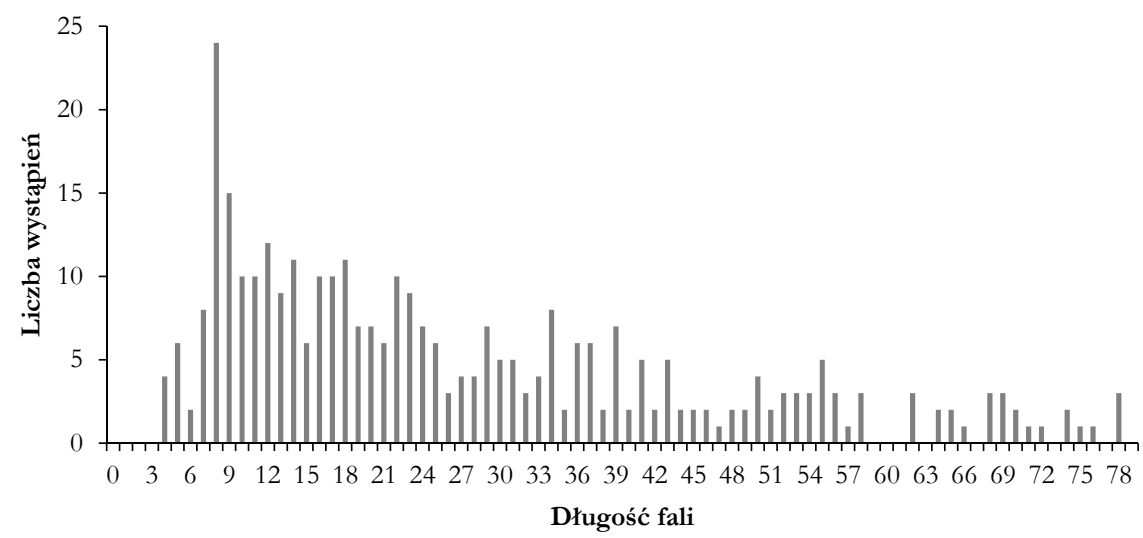

- Fale wzrostowe

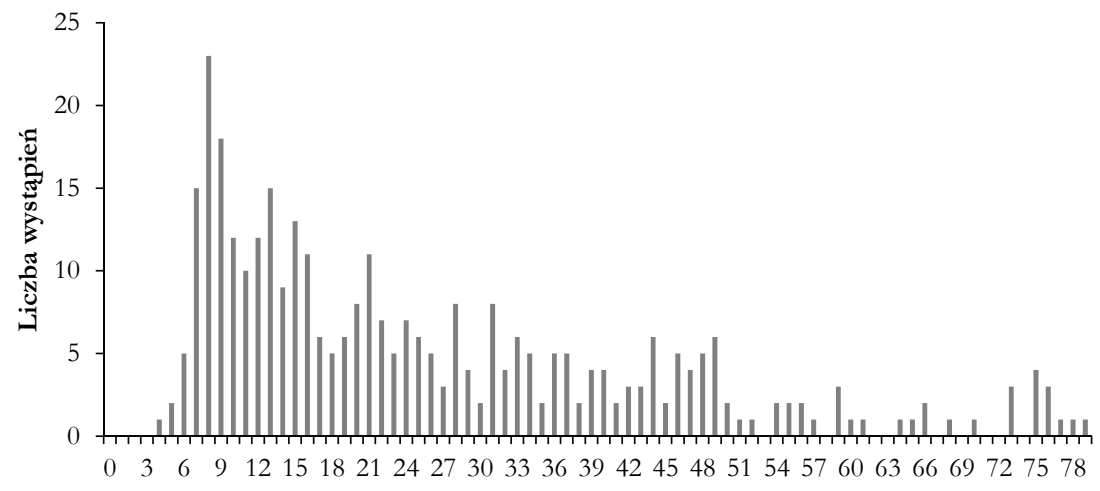

Długość fali

- Fale spadkowe

Źródło: opracowanie własne. 
Na rysunku 6. zilustrowano wyniki analogicznej analizy występowania fal o danej długości związane $\mathrm{z}$ zastosowaniem algorytmu detekcji fal w reprezentacji binarnej ADFRBK z następującymi parametrami: $m=8, p=0.7, n=0.4$. Na podstawie tych rezultatów można skonstatować, że fale o określonej długości występują częściej bądź rzadziej. Taka wiedza może zostać wykorzystana do predykcji dalszego kierunku zmian kursu walutowego USD/PLN, opartego na ocenie aktualnej długości fali. Rezultaty potwierdziły podobny kształt wykresów dla fal wzrostowych i spadkowych, co z kolei wskazuje na analogiczne zależności pomiędzy odpowiednimi falami (np. prawdopodobieństwo przełamania fali wzrostowej o długości 10 może mieć wartość bliską prawdopodobieństwu przełamania fali spadkowej o tej samej długości). Fale neutralne, reprezentujące okresy konsolidacji, charakteryzowały się natomiast krótszą długością średnią niż fale spadkowe i wzrostowe.

RYSUNEK 6.

Zależność liczby wystapień fal wzrostowych, spadkowych i neutralnych od ich długości w reprezentacji binarno-falowej - ADFRBK $(m=8, p=0.7, n=0.4)$
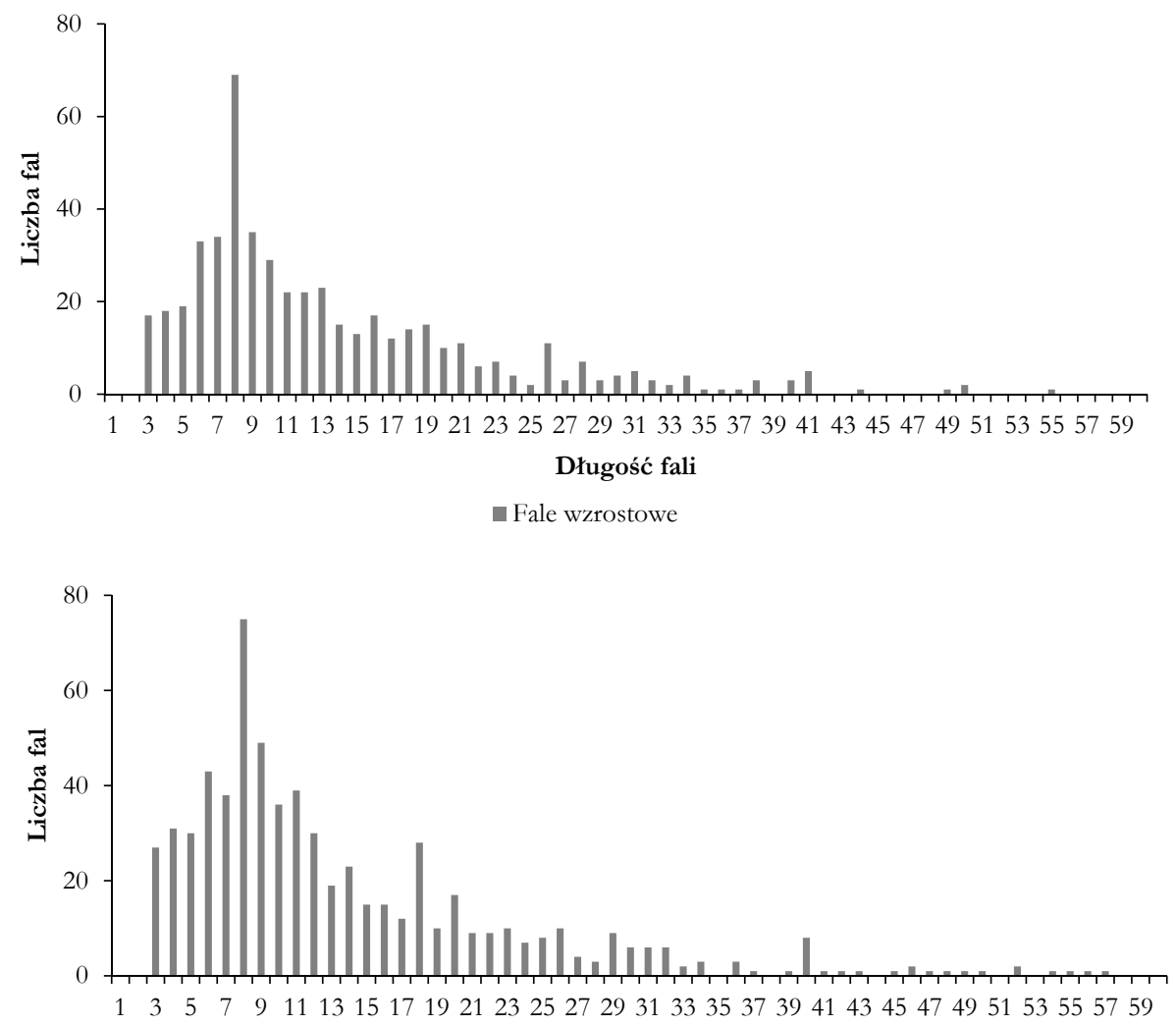

Długość fali

Fale spadkowe 


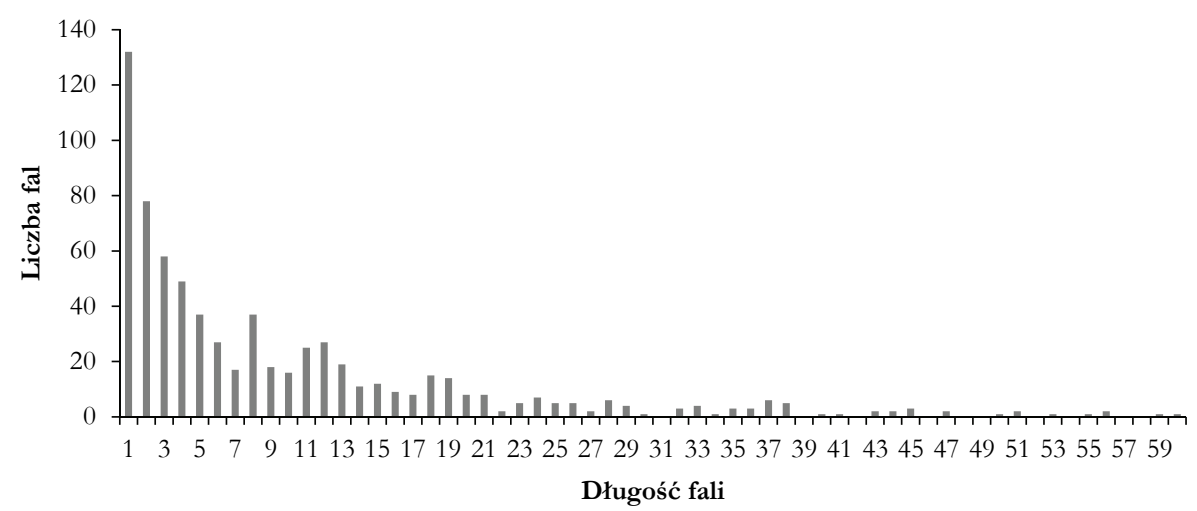

- Fala neutralna

Źródło: opracowanie własne.

W celu zweryfikowania wpływu aktualnej przynależności do fali na kierunek przyszłej zmiany kursu przeprowadzono analizę prawdopodobieństwa wzrostu lub spadku w zależności od rodzaju fali i jej długości.

RYSUNEK 7.

Prawdopodobieństwo kierunku kolejnej zmiany dla fali o długości 10

$-\operatorname{ADFRBK}(\mathrm{m}=8, \mathrm{p}=0.7, \mathrm{n}=0.4)$

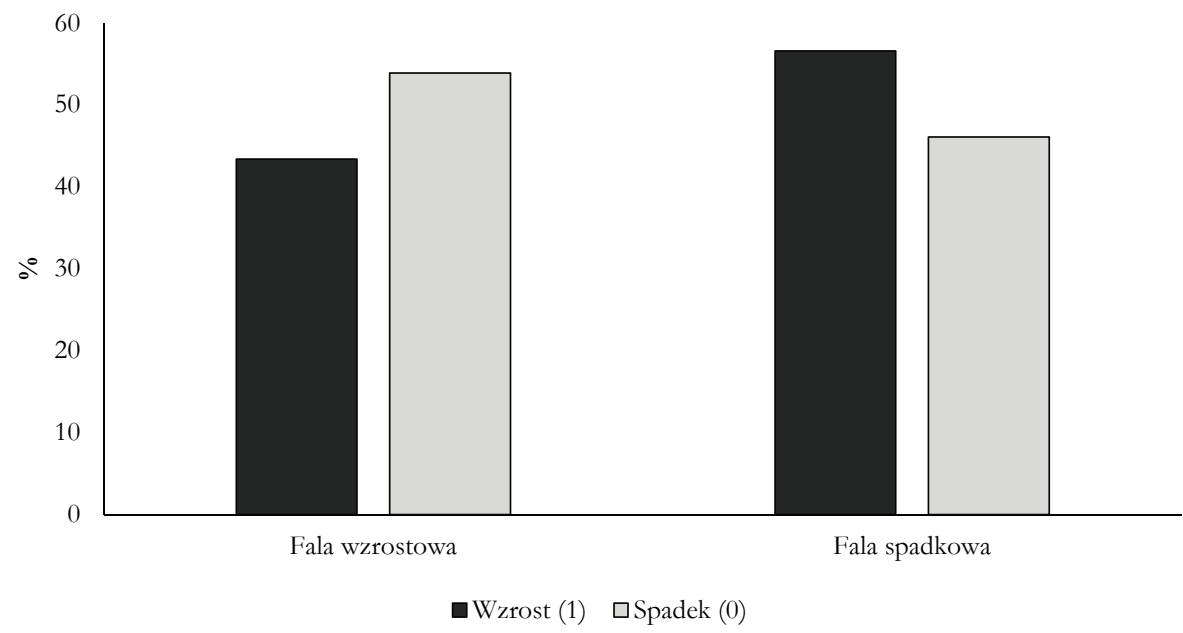

Źródło: opracowanie własne. 
Na rysunku 7. zobrazowano prawdopodobieństwo wzrostu lub spadku, gdy aktualny kurs znajduje się w fali wzrostowej bądź spadkowej o długości równej 10 . Rezultaty określono na podstawie modelu o parametrach: $m=8, p=0.7, n=0.4$. Otrzymane wyniki wskazują, że przyszły kierunek zmian kursu jest zależny od długości i rodzaju bieżącej fali. Oznacza to, że analiza falowa może być wykorzystana do konstrukcji modeli predykcyjnych, wspierających podejmowanie decyzji inwestycyjnych. Stąd warto rozważyć przykład najprostszego systemu HFT opartego na prezentowanych powyżej parametrach. System zawiera następujące transakcje: transakcję kupna (o parametrach TP (ang. Take Profit) $=$ cena+JD, SL (ang. Stop Loss) $=$ cena-JD)) w przypadku detekcji fali spadkowej o długości 10 oraz transakcję sprzedaży (o parametrach TP=cena-JD, $\mathrm{SL}=$ cena+JD) w przypadku detekcji fali wzrostowej o długości równej 10 są zawierane automatycznie. Tak skonstruowany system w badanym okresie zawierałby około 58\% zyskownych transakcji, generując dodatnią stopę zwrotu. Przykład ten dowodzi możliwości praktycznego wykorzystania analizy falowej oraz uzasadnia dalsze badania zależności falowych w celu polepszenia rezultatów predykcji.

\section{Podsumowanie}

W artykule przedstawiono dwa algorytmy detekcji fal w reprezentacji binarnej. Pierwszy algorytm ADFRB pozwolił na detekcję fal wzrostowych i spadkowych, natomiast drugi ADFRBK umożliwił detekcję fal wzrostowych, spadkowych i neutralnych (reprezentujących okresy konsolidacji). W dalszej części artykułu zaproponowano nową, binarno-falową reprezentację kursu walutowego, w której każdej zmianie kursu przypisano rodzaj bieżącej fali, określony na podstawie działania zaproponowanych algorytmów detekcji fal.

W artykule pokazano przykład analizy falowej dla danych historycznych pary walutowej USD/PLN z okresu 5 lat. Rezultaty tych badań wskazują na duże podobieństwo charakterystyk fal spadkowych i wzrostowych. Jednocześnie zauważono, że fale neutralne były zdecydowanie krótsze od fal wzrostowych i spadkowych. W artykule przeprowadzono także analizę wpływu rodzaju i parametrów bieżącej fali na kierunek przyszłych zmian kursu. Podstawą rozważań podjętych w artykule była analiza kursu pary walutowej UDS/PLN. Ukazane wyniki potwierdziły falową strukturę badanego kursu oraz istnienie statystycznych zależności między parametrami fal a prawdopodobieństwem kierunku przyszłej zmiany. Wartość tego prawdopodobieństwa dla przykładów zamieszczonych w artykule posłużyła budowie systemów HFT o dodatniej stopie zwrotu. W celu wyprowadzenia uogólnionych wniosków, w przyszłych badaniach jest planowana szersza analiza porównawcza zależności falowych w reprezentacji binarno-falowej dla innych par walutowych. 


\section{Literatura}

Bickford J. L., 2007, Forex Wave Theory-A Technical Analysis for Spot and Futures Currency Traders, The Mc-Graw-Hill Companies, New York.

Chung K. L., 2012, Elementary probability theory with stochastic processes, Springer, New York.

Frost A. J., Prechter R. R., 1995, Teoria fal Elliotta, Wig-Press, Warszawa.

Godbole A. P., Papastavridis S. G., 1994, Runs and patterns in probability: Selected papers, "Springer Science \& Business Media", vol. 283.

Lo A. W., Mamaysky H., Wang J., 2000, Foundations of technical analysis: Computational algorithms, statistical inference, and empirical implementation, "The Journal of Finance", no. 55(4).

Logue D. E., Sweeney R. J., 1977, White noise in imperfect markets: the case of the franc/dollar exchange rates, "The Journal of Finance", no. 32(3).

Menezes A. J., Van Oorschot P. C., Vanstone S. A., 1996, Handbook of applied cryptography, CRC Press, London.

Murphy J. J., 1999, Analiza techniczna rynków finansouych, WIG-Press, Warszawa.

Neely C. J., Weller P. A., 2011,Technical analysis in the foreign exchange market, Federal Reserve Bank of St. Louis Working Paper, No. 2011-001B.

Oberlechner T., 2005, The psychology of the foreign exchange market, John Wiley \& Sons, Chichester, West Sussex.

Rukhin A., Soto J., Nechvatal J., Barker E., Leigh S., Levenson M., Smid M., 2010, Statistical test suite for random and pseudorandom number generators for cryptographic applications, NIST Special Publication 800-22, Greensboro Drive McLean, VA 22102.

Schlossberg B., 2006, Technical Analysis of the Currency Market, John Wiley \& Sons, Hoboken, New Jersey.

Stasiak M. D., 2015, Kurs USD/PLN w ujeciu binarnym, Zeszyty Naukowe Uniwersytetu Ekonomicznego w Katowicach, Katowice (przyjęty do publikacji).

Stasiak M. D., 2016, Modelling of currency exchange ratesusing a binary representation, Information Systems Architecture and Technology: Proceedings of 37th International Conference on Information Systems Architecture and Technology - ISAT, Springer.

Valcu D., 2004, Using The Heikin-Ashi Technique, "Technical Analysis of Stock and Commodities Magazine", no. 22(2).

Yazdi S. H. M., Lashkari Z. H., 2013, Technical analysis of Forex by MACD Indicator, "International Journal of Humanities and Management Sciences” (IJHMS), no. 1(2). 